\title{
HUBUNGAN ANTARA SUSTAINABILITY REPORT, KINERJA PASAR, DAN KINERJA FUNDAMENTAL: BUKTI AKTOR KEPEMILIKAN PERUSAHAAN
}

\section{THE RELATIONSHIP BETWEEN STATEMENTS OF SUSTAINABILITY, MARKET PERFORMANCE AND FUNDAMENTAL PERFORMANCE: EVIDENCE OF COMPANY OWNERSHIP}

\author{
Luthpiyah Juliandara*), Siti Jahroh*), dan Budi Purwanto**) \\ *) Sekolah Bisnis, IPB University \\ Jl. Raya Pajajaran Bogor 16151, Indonesia \\ ${ }^{* *}$ Departemen Manajemen, Fakultas Ekonomi dan Manjemen, IPB University \\ Jl. Agatis, Kampus IPB Darmaga, Bogor 16880, Indonesia
}

\begin{abstract}
The importance of concern for the environment in long-term business processes and the sustainability of the company's life through the practice of sustainability report disclosure. This study aims to analyze the effect of the sustainability report and actors of company ownership on market performance and fundamental performance. The sampling technique was purposive sampling. Types and sources of data used are secondary data from annual reports and sustainability reports. The method used is factor analysis to see the contribution of indicators to variables, and path analysis to see the effect of sustainability report disclosure, using Statistical Product and Service Solutions (SPSS) tools. The findings state that the sustainability report has an effect on market performance, but the sustainability report has no effect on fundamental performance. Company ownership: BUMN and BUMS actors influence market performance and company fundamental performance.
\end{abstract}

Keywords: BUMN, BUMS, marketperformance, fundamental performance, sustainability report

\begin{abstract}
Abstrak: Pentingnya kepedulian terhadap lingkungan dalam proses bisnis jangka panjang dan keberlangsungan hidup perusahaan melalui praktik keterbukaan laporan keberlanjutan. Penelitian ini bertujuan untuk menganalisis pengaruh laporan keberlanjutan dan kepemilikan perusahaan terhadap kinerja pasar dan kinerja fundamental. Teknik pengambilan sampel adalah purposive sampling. Jenis dan sumber data yang digunakan adalah data sekunder dari laporan tahunan dan laporan keberlanjutan. Metode yang digunakan adalah analisis faktor untuk melihat kontribusi indikator terhadap variabel, dan analisis jalur untuk melihat pengaruh pengungkapan laporan keberlanjutan, dengan menggunakan tools Statistical Product and Service Solutions (SPSS). Temuan menyatakan bahwa laporan keberlanjutan berpengaruh terhadap kinerja pasar, tetapi laporan keberlanjutan tidak berpengaruh pada kinerja fundamental. Aktor kepemilikan perusahaan mempengaruhi kinerja pasar dan kinerja fundamental perusahaan.
\end{abstract}

Kata kunci: BUMN, BUMS, kinerja pasar, kinerja fundamental, laporan keberlanjutan

\footnotetext{
${ }^{1}$ Corresponding author:

Email: luthpiyah_juliandara@apps.ipb.ac.id
} 


\section{PENDAHULUAN}

Perilaku manusia yang cenderung tidak peduli terhadap kondisi sumber daya alam dan lingkungannya seperti sekarang ini, menyebabkan timbul gerakan-gerakan dimasyarakat untuk mengubah perilaku manusia yang menjadi prioritas utama dalam mengatasi krisis lingkungan. Sebab munculnya pemikiran (stigma) pelaku kerusakan lingkungan yang paling banyak merupakan masyarakat terutama masyarakat berpenghasilan rendah. Penemuan bukti bahwa penyangkalan dari penduduk lebih mungkin terjadi atas perusakan lingkungan hidup, dibanding masyarakat tersebut mesti atau harus membantu dalam pelestarian habitat atau lingkungan hidup hal tersebut dikemukakan oleh Kremer (2007). Hasil dari penelitiannya tersebut juga menjelaskan bahwa kemungkinan besar penduduk tersebut tidak melaksanakan sesuatu yang memiliki orientasi dalam upaya untuk menjaga lingkungan hidup, karena penduduk tersebut merasa bahwa dirinya ialah tidak menjaga lingkungan hidup, akan tetapi sebagai pihak yang merusak lingkunga hidup

Wahana lingkungan hidup (2013) mematahkan stigma bahwa pelaku perusakan lingkungan bukanlah masyarakat melainkan perusahaan dan bahkan perusahaan yang dimiliki oleh pemerintah. Yang menyatakan bahwa yang merupakan aktor utama dalam merusak lingkungan adalah perusahaan yaitu sebesar 39,4 persen kerusakan lingkungan diakibatkan oleh aktivitas perusahaan, aktor kedua adalah kombinasi antara perusahaan dan pemerintah yaitu sebesar 28,4 persen kerusakan lingkungan yang diakibatkan oleh aktivitas yang berkaitan dengan kekuasaan dalam hal kepentingan modal atau keterkaitan politik yang berkaitan dengan ekonomi dalam hal politik kekuasaan. aktor terendah dalam merusak lingkungan adalah masyarakat, yaitu sekitar 2,60 persen masyarakat yang berkontribusi dalam aktivitas kerusakaan lingkungan. Bentuk kerusakaan lingkungan yang terjadi diantaranya adalah pelepasan hutan dan eksplorasi.

Tingginya persentase aktor pencemaran lingkungan yang berasal dari aktivitas produksi perusahaan yang menyebabkan pemerintah menerbitkan beberapa peraturan yang diantaranya adalah mengenai tanggung jawab sosial serta lingkungan dalam peraturan pemerintahaan atau PP Tahun 2007 No 47 dan mengatur tentang lingkungan perusahaan serta tanggung jawab sosial. Dalam hal ini undang-undang Tahun 2008 No 14 mengenai hal dalam kaitannya keterbukaan informasi publik begitu penting untuk dijadikan landasan hukum yang memiliki kaitan dengan hak dari tiap-tiap orang untuk mendapatkannya. Perusahaan haruslah dapat mempertanggungjawabkan kegiatan operasional perusaahaan dan menjunjung transparansi laporan keuangannya untuk memastikan investornya terlindungi secara hukum. Chih et al. (2008) menyatakan bahwa transparansi keuangan dalam suatu perusahaan tertentu sangar penting untuk para pemegang sahamnya, dan juga pihak yang memiliki kepentingan, seperti karyawan, pelanggan, dan masyarakat karena dengan memitigasi pembentukan asimetri, informasi keuangan yang sangat transparan dapat melindungi orang luar dari eksploitasi oleh keuntungan informasi orang. Atkins (2006) berpendapat bahwa pengungkapan keuangan yang sangat transparan juga dapat menjadi elemen dari tanggung jawab sosial perusahaan.

Keberlanjutan dalam dunia bisnis telah diperkenalkan Elkington (1997) yang menyatakan bahwa keberhasilan bisnis itu terkait dengan konsep triple bottom line (3P) yang mencakup masalah lingkungan serta sosial dan juga pada hal ekonomi. Premis dasar dari triple bottom line adalah perusahaan harus berproduksi secara berkelanjutan dan, ini akan membawa lebih banyak keunggulan kompetitif untuk berkelanjutan perusahaan (Hussain et al. 2018). Santis et al. (2016) menyatakan bahwa investor bersedia membayar lebih untuk perusahaan yang berkelanjutan karena perusahaanperusahaan ini mengadopsi kebijakan CSR, transparan manajemen, memiliki tata kelola yang lebih baik, dan lebih sedikit risiko.

Beberapa tahun terakhir, dimensi lingkungan telah menjadi cukup penting dan lebih terlihat. perusahaan yang dianggap "hijau" sebagai penciptaan berkelanjutan atas pengembangan dana investasi adalah ilustrasi dari tren dimensi lingkungan. Pengungkapan perusahaan terkait lingkungan mencerminkan bagaimana suatu perusahaan, melalui tindakan atau inisiatifnya, menjadi "hijau", yaitu, dengan minimal dampak ekologis (Feier dan Haskell, 2008). Indeks SRI-Kehati merupakan pelopor investasi berkelanjutan di Indonesia melalui pasar modal. yang bertujuan untuk mendorong para investor agar lebih memperdulikan lingkungan (environmental friendly) yang mengacu pada konsep dasar pembangunan berkelanjutan sehingga semua anggota dari perusahaan yang termasuk kedalam indeks SRI-Kehati menerbitkan Sustainability Report. 
Dengan tujuan untuk mencapai atau mencerminkan suatu tingkat akuntabilitas transparansi korporat pada investor atau juga disebut stakeholders dan responsibilitas perlu dilakukannya suatu pengungkapan pada lingkup sosial, lingkungan serta juga ekonomi pada laporan tahunan di suatu perusahaan. Upaya dilakukan untuk membangun komunikasi yang baik dengan stakeholders merupakan salah satu hal lain dalam pengungkapan stakeholders dalam hal yang perlu dipastikan adalah perusahaan sudah mengungkapkan Corporate Sosial Responsibility (Darwin, 2008). Cornier (2011) menyatakan bahwa pengurangan asimetri di pasar modal dalam hal informasi bisa dilakukan dengan pengungkapan lingkungan serta pengungkapan sosial, pengurangan asimetri informasi dapat memberikan sinyal atau infromasi dari insider pada pihak luar, dan menyebabkan pengurangan ketidakpastian dari prospek peerusahaan sendiri pada kesempatan berikutnya atau waktu berikutnya dan bisa meningkatkan kesuksesan serta kredibilitas pada perusahaan dalam contoh berupa pemberian suatu informasi mengenai keuangan yang bisa di percaya serta positif. Kondisi market performance pada Indeks SRIKehati dengan Indeks LQ45 serta harga saham gabungan atau IHSG menyimpulakan Indeks SRI-Kehati lebih tinggi dibandingkan dengan IHSG dan LQ45 dalam tiga tahun terakhir (Bursa Efek Indonesia, 2019). Prospek pasaryang bagus pada Indeks SRI-Kehati tidak tercermin pada kinerja fundamentalnya, hal ini ditunjukkan oleh rata-rata return on asset beberapa sampel perusahaan sector property, perbankan dan pertambangan yang tergabung dalam Indeks SRI-Kehati jika dibandingkan kinerja fundamental pada Indeks LQ45 yang memiliki prospek pasar dibawah Indeks SRI-Kehati.

Tercermin pada perbandingan return on asset (ROA) pada kelompok Indeks SRI-Kehati dengan Indeks LQ45 yang diambil dari beberapa sektor yaitu sektor properti, sektor perbankan, dan sektor pertambangan yang terdapat pada kedua Indeks. Diketahui bahwa ROA pada Indeks LQ45 lebih tinggi dibandingkan dengan ROA pada kelompok Indeks SRI-KEHATI. Tercermin ROA tertinggi pada kelompok Indeks LQ45 pada tahun 2017 di sektor pertambangan sebesar 20,68 persen, dan pada tahun 2014 di sektor properti sebesar 14,20 persen dan pada tahun 2013 di sektor perbankan sebesar 5,03 persen sedangkan pada kelompok Indeks SRI-KEHATI pada sektor properti sebesar 7,30 persen, pada perbankan sebesar 0,02 persen dan pada sektor pertambangan sebesar 7,00 persen.
Dengan demikian kondisi pasar yang bagus pada kelompok Indeks SRI-Kehati belum bisa mencerminkan tingkatan pengembalian aset perusahaan yang lebih baik dibanding dengan perusahaan pada kelompok LQ45. Stakeholders dalam hal sebagai penelitian sebagai wujud dari pengungkapan ekonomi, serta sosial yang terus akan berkembang juga dalam hal lingkungan akan sangat menarik untuk di bahas atau di teliti. Tujuan dari hal tersebut adalah untuk bisa mengetahui atau melihat apakah selama ini pengungkapan stakeholders report mampu memberi dampak untuk perusahaan atau mungkin hanya menjadi suatu laporan dan laporan tersebut tidak di respon oleh stakeholder.

Tujuan dari penulisan ini adalah untuk mengidentifikasi perusahaan-perusahaan yang telah menerapkan konsep perusahaan berwawasan lingkungan pada perusahaan yang sudah go public; menganalisis dampak dari penerbitansutainabilityreport; mengevaluasiperbedaan karakterisktik perusahaan BUMN dan BUMS sehingga dapat dijadikan salah satu strategi untuk keberlanjutan bisnis perusahaan.

\section{METODE PENELITIAN}

Metode di dalam pelaksanaan pengumpulan data ialah dengan menggunakan cara penelusuran dari data yang bersifat sekunder pada sustainability report, statement of financial position, dan annual report periode 20122019. Sampling dilaksanakan dengan mempergunakan Teknik dengan teknik purposive sampling dengan non probability sampling. Metode analisis yang digunakan adalah analisis faktor yang melihat kontribusi indikator terhadap variabel, dan analisis jalur untuk melihat pengaruh pengungkapan laporan keberlanjutan dan laporan kinerja fundamental. Serta laporan yang menampilkan pengungkapan kinerja ekonomi, kinerja sosial, dan kinerja lingkungan baik dalam laporan keuangan, laporan tahunan, maupun laporan berkelanjutan perusahaan yang tergabung dalam Indeks SRI-KEHATI dan Indeks LQ45 2013-2019.

Kerangka berpikir penelitian ini merupakan keterkaitan antara tahapan tujuan penelitian dan tahapan penelitian. Yang bertujuan untuk menganalisis dampak dari penerbitan sutainability report dan mengevaluasi perbedaan karakterisktik perusahaan BUMN dan BUMS. Konsep dasar keberlanjutan adalah praktik dalam mengukur dan mengungkapkan aktivitas perusahaan sebagai tanggung jawab kepada 
seluruh stakeholders terkait kinerja organisasi dalam mewujudkan tujuan pembangunan berkelanjutan. Keterbukaan laporan keberlajutan terdiri dari informasi yang berkaitan dengan kegiatan korporasi, aspirasi, dan citra publik mengenai lingkungan, masalah masyarakat, karyawan, dan konsumen yang menjadi salah satu media untuk mendeskripsikan pelaporan ekonomi, lingkungan, dan dampak sosial.

Pengungkapan sustainability report yang signifikan dapat digunakan sebagai sumber informasi dalam proses pengambilan keputusan investasi (Belkaoui, 1984). Cornier (2011) menyatakan bahwa pengungkapan sosial dan pengungkapan lingkungan dapat mengurangi asimetri informasi di pasar modal. Pengurangan asimetri informasi dapat memberikan sinyal atau infromasi dari insider kepada pihak luar. Hal ini dapat berupa informasi keuangan yang positif dan dapat dipercaya sehingga dapat mengurangi ketidakpastian mengenai prospek perusahaan yang akan datang.

Penelitian Spence (1973) menyebutkan bahwa signal memberikan informasi yang dapat dimanfaatkan oleh pihak penerima informasi. Informasi yang dikirim berupa informasi mengenai pengungkapan sustainability report perusahaan. Adapun informasi yang berkaitan dengan pengungkapan ekonomi, sosial, dan lingkungan akan direspons positif oleh masyarakat sehingga mampu meningkatkan citra perusahaan. Ketika informasi diumumkan ke publik dan seluruh pelaku pasar sudah menerima informasi mengenai prospek bisnis perusahaan, pelaku pasar akan terlebih dahulu menginterpretasi dan menganalisis informasi tersebut sebagai signal baik (good news) atau signal buruk (bad news) (Jogiyanto, 2010). Faktor kepemilikan, baik BUMN maupun BUMS, sangatlah penting untuk diteliti pada penelitian ini karena dapat melihat perbedaan antara BUMN yang mengungkapkan sustainability report dengan pihak BUMS. AlNajjar (2015) mengatakan, adanya kepemilikan institusional pengawasan terhadap pihak manajemen akan lebih ketat sehingga hak-hak pemegang saham dapat terlindungi. Hal ini menjelaskan kalau terdapat perbedaan antara kepemilikan pemerintah dengan swasta dalam menghasilkan nilai kinerja fundamental ataupun kinerja pasar perusahaan. Aerts et al. (2006) mengatakan, perusahaan dengan kapitalisasi pasar yang besar memerlukan lebih banyak informasi dan memberikan tingkat pengembalian yang tinggi untuk memungkinkan para perusahaan terlibat lebih banyak dengan para pemangku kepentingan. Berdasarkan uraiuan tersebut maka hipotesis penelitian ini antara lain:

H1: Pengungkapan sustainabilit report berpengaruh signifikan terhadap kinerja pasar

H2: Pengungkapan sustainability report berpengaruh tidak signifikan terhadap fundamental value

H3: Kinerja fundamental berpengaruh signifikan terhadap kinerja pasar

H4: Aktor kepemilikan perusahaan berpengaruh signifikan terhadap kinerja fundamental

H5: Aktor kepemilikan perusahaan berpengaruh signifikan terhadap kinerja pasar

\section{HASIL}

\section{Penerapan konsep perusahaan berwawasan lingkungan pada perusahaan yang sudah Go Public}

Di dalam perusahaan yang sudah go public berdasarkan data perusahaan yang terdaftarkan pada Indonesia Sustainability Report Reporting Awards (ISRA), terdapat tren positif dari pengungkapan sustainability report di Indonesia pada tahun 2005-2019. Dalam periode yang digunakan dalam penelitian, yaitu periode 2013-2019, terjadi tiga kali penurunan pada tren perusahaan partisipan ISRA. Pada tahun 2014 terjadi penurunan jumlah partisipan sebanyak satu perusahaan partisipan ISRA dan pada tahun 2017 terjadi penurunan sebanyak 10 perusahaan partisipan ISRA. Kemudian, mengalami peningkatan jumlah partisipan ISRA pada tahun 2018, yaitu sebanyak 56. Namun, kembali mengalami penurunan pada tahun 2019, yakni berjumlah 48 perusahaan terdaftar sebagai partisipan ISRA 2019.

Trend pelaksanaan penjelasan dari Sustainability report yang terdapat pada Negara Indonesia walaupun sustainability report yang ada di Negara Indonesia hanya sebatas laporan yang sifatnya sekedar sukarela. Hampir 9\% dari keseluruhan perusahaan yang listing di BEI, yang sudah melaksanakan sustainability report. Dan sisanya, sebanyak $91 \%$ perusahaan yang listing di BEI, belum melakukan pengungkapan sustainability report. 
Dari $9 \%$ tersebut, jika dikelompokkan berdasarkan sektornya, persentase terendah terdapat pada sektor industri barang konsumsi, yaitu sebesar 3,57\% atau sebanyak dua perusahaan yang melakukan pengungkapan sustainability report. Kemudian, diikuti oleh sektor aneka industri sebesar 5,36\% atau tiga perusahaan. Kemudian 7,14\% pada sektor perdagangan, jasa, investasi, serta industri dasar dan kimia masingmasing 4 perusahaan. Pada sektor pertanian, sebesar $8,93 \%$ atau 5 perusahaan yang telah melaporkan. Sektor properti, real estate, dan konstruksi bangunan sebesar $10,71 \%$ atau sebanyak 7 perusahaan. Sektor mining dan infrastruktur sebanyak 9 perusahaan $(16,4 \%$ dari jumlah perusahaan sektor mining dan infrastruktur). Persentase tertinggi terdapat pada sektor keuangan, yaitu sebesar $25 \%$ atau sebanyak 14 perusahaan, yang melakukan pengungkapan sustainability report.

Jika dibandingkan dengan sektor lain, sektor keuangan memiliki proporsi jumlah pengungkapan tertinggi, yaitu sebesar 25\% atau sebanyak 14 perusahaan. Keempat belas perusahaan tersebut terdiri dari 10 perusahaan perbankan buku 3 (bank dengan modal inti sebesar Rp5 Triliun-Rp30 Triliun yang menerbitkan sustainability report dari total perusahaan perbankan buku 3 sebanyak 24 perusahaan perbankan, dan empat perusahaan perbankan buku 4 (bank dengan modal inti sebesar lebih dari sama dengan Rp30 Triliun) yang menerbitkan sustainability report dari total perusahaan perbankan buku 4 sebanyak 4 perusahaan perbankan.

Dilihat dari status kepemilikan perusahaan antara pemerintah (BUMN) dengan swasta, menunjukkan bahwa perusahaan pemerintah (BUMN) memiliki persentase yang lebih besar, yakni sebesar 52\%, jika dibandingkan dengan perusahaan swasta, yaitu hanya $48 \%$ perusahaan yang melakukan pengungkapan sustainability report. Selisih dari keduanya adalah $4 \%$. Persentase yang lebih rendah pada perusahaan swasta bukan disebabkan oleh rendahnya kepedulian perusahaan, tetapi disebabkan oleh sifat laporan yang cenderung sukarela (voluntary), sehingga perusahaan tidak setiap tahun menerbitkan sustainability report.

\section{Analisis Faktor}

Variabel laporan keberlanjutan

Indikator EcDI (Economic Disclosure Indeks) memiliki nilai korelasi dengan variabel laporan keberlanjutan sebesar 0,906. dan indikator SoDI (Social Disclosure
Indeks) memiliki nilai korelasi dengan variabel laporan keberlanjutan sebesar 0,950. sedangkan indikator EnDI Environment Disclosure Indeks) memiliki nilai korelasi dengan variabel laporan keberlanjutan sebesar 0,918.

Variabel kinerja fundamental

Indikator ROE (Retutn On Equity)cmemiliki nilai korelasi dengan variabel kinerja fundamental sebesar 0,779. dan indikator TATO (Total Aset Turnover) memiliki nilai korelasi dengan variabel kinerja fundamental sebesar 0,816 .

\section{Dampak dari penerbitan sutainability report hasil analisis full model tanpa variabel kontrol}

$$
\begin{array}{ll}
Y=P_{y x 1} X_{1}+P_{y x 2} X_{2}+P_{y \times 3} X_{3}+e_{y} & \text { Substruktur 1 } \\
X_{3}=P_{x 3 \times 1} X_{1}+P_{x 3 x 2} X_{2}+e_{x 3} & \text { Substruktur } 2
\end{array}
$$

Hasil dugaan parameter model substruktur 1 menunjukkan bahwa variabel bebas Sustainability Report $\left(\mathrm{X}_{1}\right)$ dan aktor perusahaan $\left(\mathrm{X}_{2}\right)$ memiliki keterikatan dengan kinerja pasar (Y). Sementara itu, kinerja fundamental $\left(\mathrm{X}_{3}\right)$ tidak memiliki pengaruh yang signifikan terhadap variabel terikat kinerja pasar (Y). Pada hasil dugaan parameter model substruktur 2, variabel bebas sustainability report $\left(\mathrm{X}_{1}\right)$ tidak memiliki pengaruh yang signifikan terhadap kinerja fundamental. Sementara itu, aktor kepemilikan $\left(X_{2}\right)$ perusahaan memiliki pengaruh yang signifikan terhadap kinerja fundamental $\left(\mathrm{X}_{3}\right)$ dan tidak memiliki pengaruh yang signifikan terhadap kinerja pasar $(\mathrm{Y})$. pengungkapan Sustainability Report yang dilakukan oleh perusahaan yang berisi mengenai informasi ekonomi, informasi sosial, dan informasi lingkungan dapat memberikan signal positif terhadap investor dan pemangku kepentingan. Dan sesuai denga teori signaling yang menyatakan bahwa Perusahaan akan mampu meningkatkan nilai dari perusahaan jika asimetri informasi ini dapat diminimalisasi.

Pengaruh pengungkapan sustainability report terhadap kinerja pasar menurut Solomon dan Solomon (2006) menyatakan bahwa perusahaan yang melakukan pengungkapan social dan lingkungan yang unggul dapat menarik dan dapat memberikan dampak yang besar terhadap pengambilan keputusan di pasar modal. Sedangkan pada kinerja fundamental, Solomon dan Solomon (2006) menyatakan bahwa perusahaan yang melakukan pengungkapan social dan lingkungan yang unggul dapat menarik dan dapat memberikan dampak 
yang besar terhadap pengambilan keputusan di pasar modal. Abiodun (2012) mempelajari hubungan antara pengungkapan Sustainability Report dan fundamental perusahaan di Nigeria menunjukkan hubungan negatif antara kinerja fundamental perusahaan dan pengungkapan Sustainability Report, menyiratkan organisasi yang menguntungkan di Nigeria tidak berinvestasi banyak dalam kegiatan social lingkungan. Pada aktor kepemilikan perusahaan mampu memengaruhi kebijakan dan keputusan manajemen untuk melakukan proses bisnis seperti keinginannya sebagai pemilik. Namun pasar belum tentu merespon secara positif setiap kegiatan yang akan dilakukan oleh perusahaan. Kinerja fundamental sendiri, diperoleh dari pengambilan keputusan jangka panjang yang dilakukan perusahaan, baik dari kebijakan mengenai cara perusahaan menjaga profitabilitas ataupun kebijakan pendanaan yang dilakukan perusahaan untuk melakukan aktivitas selama dalam kurun waktu tertentu. Hal ini lah yang nantinya akan dilihat oleh investor untuk mengetahui arah bisnis perusahaan di masa mendatang.

Kebaikan Model

$$
\begin{aligned}
\text { Gof }=\mathrm{Q} 2 & =1-\{(1-\mathrm{R} 1)(1-\mathrm{R} 2)(1-\mathrm{R} 3)\} \\
& =1-\{(1-0,05)(1-0.67)\}=0.6865
\end{aligned}
$$

Dari perhitungan di atas diperoleh nilai Q2 $=0,6865$. artinya $68,65 \%$ keragamanvariabel terikatdiprediksikan variable bebas. Sementaran itu lainya dijelaskan oleh variabel lain yang tidak terdapat dalam peneliyian

\section{Dampak dari penerbitan sutainability report hasil analisis full model dengan variabel kontrol}

$$
\begin{array}{r}
\mathrm{Y}=\mathrm{P}_{\mathrm{yx1} 1} \mathrm{X}_{1}+\mathrm{P}_{\mathrm{yx} 2 \mathrm{X}_{2}+\mathrm{P}_{\mathrm{yx3} 3} \mathrm{X}_{3}+\mathrm{P}_{\mathrm{yx} 4} \mathrm{X}_{4}+\mathrm{P}_{\mathrm{yx} 5} \mathrm{X}_{5}+\mathrm{e}_{\mathrm{y}}}^{\text {Substruktur } 1 \mathrm{~b}} \\
\mathrm{X}_{3}=\mathrm{P}_{\mathrm{x} 3 \mathrm{x} 1} \mathrm{X}_{1}+\mathrm{P}_{\mathrm{x} 3 \times 2} \mathrm{X}_{2}+\mathrm{P}_{\mathrm{x} 3 \times 3} \mathrm{X}_{3}+\mathrm{P}_{\mathrm{x} 3 \mathrm{x} 4} \mathrm{X}_{4}+\mathrm{e}_{\mathrm{x} 3}
\end{array}
$$$$
\text { Substruktur } 2 \mathrm{~b}
$$

Hasil dugaan parameter model substruktur $1 \mathrm{~b}$ menyatakan bahwa variabel bebas sustainability report $\left(\mathrm{X}_{1}\right)$, aktor perusahaan $\left(\mathrm{X}_{2}\right)$, sektoral sebagai variabel kontrol sektoral $\left(\mathrm{X}_{4}\right)$, dan kinerja fundamental $\left(\mathrm{X}_{3}\right)$ memiliki sumbangan pengaruh signifikan terhadap variabel terikat kinerja pasar (Y). Sementara itu, pada variabel kontrol market capital $\left(\mathrm{X}_{4}\right)$ tidak terdapat pengaruh terhadap kinerja pasar $(\mathrm{Y})$. Pada hasil dugaan parameter model substruktur $2 \mathrm{~b}$, variabel bebas sustainability report $\left(\mathrm{X}_{1}\right)$ tidak memiliki sumbangan pengaruh yang signifikan terhadap kinerja fundamental $\left(\mathrm{X}_{3}\right)$ dan memiliki sumbangan pengaruh yang signifikan terhadap kinerja pasar (Y). Sementara itu, aktor kepemilikan $\left(\mathrm{X}_{2}\right)$ perusahaan memiliki sumbangan pengaruh yang signifikan terhadap kinerja fundamental $\left(\mathrm{X}_{3}\right)$ dan memiliki sumbangan pengaruh signifikan terhadapkinerjapasar(Y).Terdapatsumbanganpengaruh sektoral $\left(\mathrm{X}_{4}\right)$ terhadap kinerja fundamental $\left(\mathrm{X}_{3}\right)$. Tidak terdapat sumbangan pengaruh variabel market capital $\left(\mathrm{X}_{5}\right)$ terhadap kinerja fundamental $\left(\mathrm{X}_{3}\right)$. Variabel control market cavital tidak dapat mengontrol naik turunnya nilai kinerja pasar perusahaan. variable control market cavital tidak dapat mengontrol naik turunnya nilai kinerja pasar perusahaan. Kegiatan pengoprasian dari perusahaan non-perbankan lebih banyak merasakan dampak berkenaan dengan lingkungan dibadning pada pengoperasian dari perusahaan perbankan. Jasa dan produk yang dihasilkan perusahaan keuangan tidak memiliki keterkaitan langsung pada lingkungan, sementara itu jasa dan produk dari perusahaan seperti jasa konstruksi, semen, batu bara memiliki keterkaitan secara langsung pada etika lingkungan.

Hasil pada kinerja fundamental Memakai atau Tidak memakai variable control, sustainability report akan memiliki dampak bagi perusahaan besar untuk membangun citra perusahaan. Charles JK (2017) menyatakan bahwa Terlepas dari kenyataan bahwa investor di Polandia memperhatikan korelasi positif antara pendekatan yang bertanggung jawab untuk melakukan bisnis dan hasil keuangan, mereka cenderung tidak memperhitungkan kinerja sosial saat membuat keputusan investasi.

Dampak pada kinerja pasar dan kinerja fundamental jika dikelompokan berdasarkan aktor kepemilikan (BUMN/ BUMS) dan dikontrol dengan variable sectoral dan marketcavital. Tingginya kinerjapasar suatu perusahaan jika dikontrol berdasarkan sektoral tidak dilihat dari kepemilikan perusahaan tersebut, apakah dengan kepemilikan BUMN atau BUMS. perusahaan dengan kapitalisasi pasar yang besar memerlukan lebih banyak informasi dan memberikan tingkat pengembalian yang tinggi untuk memungkinkan para perusahaan terlibat lebih banyak dengan para pemangku kepentingan yang tidak dibatasi apakah perusahaan termasuk kedalam sektor perbankan atau non-perbankan. Sedangkan pada kinerja fundamental, tidak ada perbedaan secara signifikan tingkat pengungkapan keberlanjutan antara actor kepemilikan yang dibatasi sektor perbankan 
dan non-perbankan. Hal tersebut berarti perusahaan yang dimiliki pemerintah ataupun swasta sama-sama memiliki pengaruh dalam pengambilan keputusan untuk pihak manajemen.

\section{Kebaikan Model}

$$
\begin{aligned}
\text { Gof }=\mathrm{Q}^{2} & =1-\left\{\left(1-\mathrm{R}_{1}\right)\left(1-\mathrm{R}_{2}\right)\left(1-\mathrm{R}_{3}\right)\right\} \\
& =1-\{(1-0,088)(1-0,655)\}=0,68536
\end{aligned}
$$

Dari perhitungan diperoleh nilai $\mathrm{Q}^{2}=\mathbf{0 , 6 8 5 3 6}$. Hal ini menunjukan $\mathbf{6 8 , 5 3 6} \%$ keragaman variabel terikat dijelaskan oleh variabel bebas. Sisanya dijelaskan oleh variabel lain yang tidak terdapat dalam model.

\section{Perbedaan karakterisktik perusahaan BUMN dan BUMS}

Untuk menguji perbedaan karakteristik perusahaan BUMN dan BUMS yang menerbitkan sustainability repot maka pada penelitian ini dilakukan pengujian berdasarkankarakterisikperusahaan BUMNdanBUMS. Pengujian ini dilakukan dengan membandingkan antara hasil pengujian yang menggunakan variabel kontrol dan tidak menggunakan variabel kontrol. Variabel kontrol yang digunakan adalah variabel kontrol sektoral dan variabel kontrol market cavital.

\section{Hasil analisis model swasta tanpa variabel kontrol}

$$
\begin{array}{ll}
\mathrm{Y}=\mathrm{P}_{\mathrm{yx} 1} \mathrm{X}_{1}+\mathrm{P}_{\mathrm{yx} 2} \mathrm{X}_{2}+\mathrm{ey} & \text { Substruktur 3a } \\
\mathrm{X}_{2}=\mathrm{P}_{\mathrm{x} 2 \times 1} \mathrm{X}_{1}+\mathrm{e}_{\mathrm{x} 2} & \text { Substruktur 4a }
\end{array}
$$

Pada hasil dugaan parameter model substruktur 3a, variabel bebas sustainability report $\left(\mathrm{X}_{1}\right)$ tidak memiliki sumbangan pengaruh yang signifikan terhadap variabel terikat kinerja pasar (Y). Sementara itu, kinerja fundamental $\left(\mathrm{X}_{3}\right)$ memiliki sumbangan pengaruh signifikan terhadap variabel terikat kinerja pasar (Y). Hasil dugaan parameter model substruktur 4a adalah variabel bebas sustainability report $\left(\mathrm{X}_{1}\right)$ tidak memiliki sumbangan pengaruh yang signifikan terhadap kinerja fundamental dan kinerja pasar (Y). Masih ada perusahaan yg tidak menerbitkan sustainability report,dikarenakan tanpa menerbitkan sustainability report pun nilai Kinerja Pasar dan kinerja Fundamental perusahaan BUMS sudah baik, jadi tidak sulit untuk manjemen menarik investor agar mau berinvestasi diperusahaanya.
Kebaikan Model

$$
\begin{aligned}
\text { Gof }=\mathrm{Q}^{2} & =1-\left\{\left(1-\mathrm{R}_{1}\right)\left(1-\mathrm{R}_{2}\right)\left(1-\mathrm{R}_{3}\right)\right\} \\
& =1-\{(1-0,015)(1-0,573)\}=0,5794
\end{aligned}
$$

Dari perhitungan diperoleh nilai $\mathrm{Q}^{2}=\mathbf{0 , 5 7 9 4}$. Hal ini menunjukan, $\mathbf{5 7 , 9 4} \%$ keragaman variabel terikat dijelaskan oleh variabel bebas. Sisanya dijelaskan oleh variabel lain yang tidak terdapat dalam model.

\section{Hasil Analisis Model BUMS dengan Variabel Kontrol}

$\mathrm{Y}=\mathrm{P}_{\mathrm{yx} 1} \mathrm{X}_{1}+\mathrm{P}_{\mathrm{yx} 4} \mathrm{X}_{4}+\mathrm{P}_{\mathrm{yx} 5} \mathrm{X}_{5}+\mathrm{P}_{\mathrm{yx} 3} \mathrm{X}_{3}+\mathrm{e}_{\mathrm{y}}$ Substruktur $3 \mathrm{~b}$ $\mathrm{X}_{3}=\mathrm{Px}_{3 \times 1} \mathrm{X}_{1}+\mathrm{P}_{\mathrm{x} 3 \times 4} \mathrm{X}_{4}+\mathrm{P}_{\mathrm{x} 3 \mathrm{x} 5} \mathrm{X}_{5}+\mathrm{e}_{\mathrm{x} 3} \quad$ Substruktur $4 \mathrm{~b}$

Hasil dugaan parameter model substruktur $3 \mathrm{~b}$ menunjukkan bahwa variabel bebas sustainability report $\left(\mathrm{X}_{1}\right)$, variabel kontrol sektoral $\left(\mathrm{X}_{4}\right)$, dan market capital $\left(\mathrm{X}_{5}\right)$ tidak memiliki sumbangan pengaruh yang signifikan terhadap variabel terikat kinerja pasar $(\mathrm{Y})$. Sementara itu, kinerja fundamental $\left(\mathrm{X}_{3}\right)$ memiliki sumbangan pengaruh signifikan terhadap variabel terikat kinerja pasar $(\mathrm{Y})$, pada substruktur $4 \mathrm{~b}$ tidak ada variabel yang signifikan memberikan sumbangan pengaruh terhadap kinerja fundamental.

\section{Sektoral dan market capital sebagai variabel kontrol pada model swasta}

Berdasarkan hasil uji statistik, penggunaan variabel sektoral dan market capital berpredikat sebagai variabel kontrol menghasilkan hasil yang berbeda antara yang mempergunakan variabel kontrol dengan variabel yang tidak mempergunakan variabel kontrol. Ditampilkan dalam Tabel 1.

Peraturan Pemerintah tentang Tanggung Jawab Sosial dan Lingkungan (TJSL) atau yang umunya CSR perusahaan sebenarnya sudah diatur pada Pasal 74 ayat (4) Undang-Undang Nomor 40 Tahun 2007 berkenan dengan Perseroan Terbatas. Namun sebagian besar perusahaan swasta masih hanya sebatas menjalankan aturan yang telah diatur pemerintah terkait CSR, belum sampai ke penerbitan laporan sustainability report.

Hasil ini telah diuji menggunakan model dengan variabel kontrol maupun tanpa variabel kontrol. Dan hasil dari penelitian menunjukan konsistensi yang menyatakan bahwa dikontrol atau tidaknya model ini, baik dengan menggunakan variabel sektoral maupun 
market capital, bahwa pengungkapan sustainability report pada perusahaan dengan kepemilikan BUMS tidak memberikan sumbangsing pengaruh secara langsung maupun secara tidak langsung pada kinerja pasar perusahaan. teori signaling tidak dapat dibuktikan pada perusahaan dengan kepemilikan BUMS. Masih ada perusahaan yg tidak menerbitkan sustainability report,dikarenakan tanpa menerbitkan sustainability report pun nilai Kinerja Pasar dan kinerja Fundamental perusahaan BUMS sudah baik, jadi tidak sulit untuk manjemen menarik investor agar mau berinvestasi diperusahaanya. Baik dikontrol dengan sectoral maupun tidak.

\section{Kebaikan Model}

Total nilai $\mathrm{R}^{2}$ digunakan untuk menghitung Goodness of Fit (GOF). Nilai GOF digunakan untuk menunjukkan apakah suatu model fit atau tidak. Dari analisis didapatkan nilai $\mathrm{R}^{2}=0,45$. Hal ini menunjukan, 45\% keragaman variabel terikat dijelaskan oleh variabel bebas. sisanya dijelaskan oleh variabel lain yang tidak terdapat dalam model.

\section{Hasil Analisis Model BUMN Tanpa Variabel Kontrol}

$\mathrm{Y}=\operatorname{Pyx} 1 \mathrm{X} 1+\operatorname{Pyx} 2 \mathrm{X} 2+$ ey $\quad$ Substruktur 5

$\mathrm{X} 2=\mathrm{Px} 2 \mathrm{x} 1 \mathrm{X} 1+\mathrm{ex} \quad$ Substruktur 6

Hasil dugaan parameter model substruktur 5a terlihat bahwa variabel bebas sustainability report $\left(\mathrm{X}_{1}\right)$ dan kinerja fundamental $\left(\mathrm{X}_{3}\right)$ memiliki sumbangan pengaruh yang signifikan terhadap variabel terikat kinerja pasar $(\mathrm{Y})$. Pada hasil dugaan parameter model substruktur 6a, variabel bebas sustainability report $\left(\mathrm{X}_{1}\right)$ tidak memiliki sumbangan pengaruh yang signifikan terhadap kinerja fundamental dan kinerja pasar (Y). Hasil ini mengindikasikan bahwa aktor kepemilikan swasta yang menerbitkan sustainability report tidak memiliki dampak yang signifikan terhadap perubahan kinerja perusahaan, baik dari sisi fundamental maupun kinerja pasar perusahaan. Hal ini disebabkan perusahaan swasta di Indonesia masih berorientasi pada profit. Dengan demikian, penerbitan sustainability report masih dianggap sebagai tambahan biaya pengeluaran perusahaan.

Hasil ini telah diuji menggunakan model dengan variabel kontrol dan tanpa variabel kontrol. Hasilnya penelitian menunjukan konsistensi yang menyatakan bahwa dikontrol atau tidaknya model ini, baik dengan menggunakan variabel sektoral maupun market capital, pengungkapan sustainability report pada perusahaan dengan kepemilikan BUMS tidak memiliki pengaruh langsung dan tidak langsung terhadap kinerja pasar perusahaan. Oleh karena itu, teori signaling tidak dapat dibuktikan pada perusahaan dengan kepemilikan BUMS. Menerbitkan sustainability report merupakan nilai lebih bagi mereka, karna mereka menyadari nilai fundamental yang lebih kecil dibandingkan BUMS membuat investor ragu untuk berinvestasi terhadap perusahaan yang menyebabkan nilai kinerja pasar BUMN lebih kecil disbanding BUMS. Maka dari itu pihak manajemen mensiasati dengan melakukan pengungkapan sustainability report untuk meningkankan value perusahaan sehingga investor tertarik untuk berinvestasi

Kebaikan Model

Gof $=\mathrm{Q} 2=1-\{(1-\mathrm{R} 1)(1-\mathrm{R} 2)(1-\mathrm{R} 3)\}=1-\{(1-0,008)$ $(1-0,384)\}=0,3889$

Dari perhitungan di atas diperoleh nilai Q2 $=0,3889$. Hal ini menunjukan 38,89\% keragaman variabel terikat dijelaskan oleh variabel bebas. sisanya dijelaskan oleh variabel lain yang tidak terdapat dalam model.

Tabel 1. Pengaruh sektoral dan market capital sebagai variabel kontrol pada model BUMS

\begin{tabular}{lcc}
\hline \multicolumn{1}{c}{ Keterangan } & Tanpa Variabel kontrol & Dengan Variabel kontrol \\
\hline Terhadap kinerja pasar & $57,3 \%$ & $45 \%$ \\
Adjusted $\mathrm{R}^{2}$ & Negatif dan tidak signifikan & Negatif dan tidak signifikan \\
Sustainability report & Positif dan signifikan & Positif dan signifikan \\
Kinerja fundamental & & $0 \%$ \\
Terhadap kinerja fundamental & $1,5 \%$ & Negatif dan tidak signifikan \\
Adjusted $\mathrm{R}^{2}$ & Negatif dan tidak signifikan & \\
Sustainability report &
\end{tabular}


Hasil Analisis Model BUMN dengan Variabel Kontrol

$$
\begin{gathered}
\mathrm{Y}=\mathrm{P}_{\mathrm{yx1} 1} \mathrm{X}_{1}+\underset{\mathrm{yx4}}{\mathrm{P}_{\mathrm{y} 4} \mathrm{X}_{4}+\mathrm{P}_{\mathrm{y} \times 5} \mathrm{X}_{5}+\mathrm{P}_{\mathrm{yx3} 3} \mathrm{X}_{3}+\mathrm{e}} \\
\text { Substruktur } 5 \mathrm{~b} \\
\mathrm{X}_{3}=\mathrm{P}_{\mathrm{x} 3 \mathrm{x} 1} \mathrm{X}_{1}+\mathrm{P}_{\mathrm{x} 3 \times 4} \mathrm{X}_{4}+\mathrm{P}_{\mathrm{x} 3 \times 5} \mathrm{X}_{5}+\mathrm{e}_{\mathrm{x} 3} \\
\text { Substruktur } 6 \mathrm{~b}
\end{gathered}
$$

Hasil dugaan parameter model substruktur 5b menunjukkan bahwa variabel bebas sustainability report $\left(\mathrm{X}_{1}\right)$ dan kinerja fundamental $\left(\mathrm{X}_{3}\right)$ memiliki pengaruh yang signifikan terhadap variabel terikat kinerja pasar (Y). Sementara itu, variabel kontrol sektoral $\left(\mathrm{X}_{4}\right)$ dan market capital $\left(\mathrm{X}_{5}\right)$ tidak memiliki pengaruh terhadap kinerja pasar $(\mathrm{Y})$. Selanjutnya, hasil dugaan parameter model substruktur $6 \mathrm{~b}$ terlihat bahwa variabel bebas sustainability report $\left(\mathrm{X}_{1}\right)$ dan variabel kontrol market capital $\left(\mathrm{X}_{4}\right)$ tidak memiliki pengaruh yang signifikan terhadap kinerja fundamental $\left(\mathrm{X}_{3}\right)$, tetapi memiliki pengaruh yang signifikan terhadap kinerja pasar (Y). Sementara itu, variabel kontrol sektoral memiliki pengaruh terhadap kinerja pasar (Y) dan kinerja fundamental $\left(\mathrm{X}_{3}\right)$.

\section{Sektoral dan market kapital sebagai variabel kontrol pada model BUMN}

Berdasarkan hasil uji statistik, penggunaan variabel sektoral dan market capital menunjukkan adanya perbedaan hasil antara variabel yang menggunakan kontrol dan tanpa kontrol. Pada hasil pengujian tanpa menggunakan variabel kontrol nilai Adjusted $\mathrm{R}^{2}$ pada model BUMN cenderung lebih fluktuatif dibandingkan dengan yang menggunakan variabel kontrol. Untuk hasil lengkapnya seperti yang disajikan pada Tabel 2.

Mengacu pada Undang Undang Badan Usaha Milik Negara No 13 Tahun 2003 mewajibkan kepada perusahaan yang berjenis BUMN untuk mengindahkan 194 permasahaan berkenaan dengan social dengan cara memperhatikan pada Program Kemitraan dan Bina Lingkungan (PKBL). Sementara itu, berkiblat pada Undang Perseroan Terbatas No 40 Tahun 2007 memberikan himbauan kepada entitas yang berjenis perseroan terbatas untuk melaksanakan pertanggungjawaban berkenaan dengan Corporate Social Responsibilty (CSR). Sementara itu, menjelaskan bahwa program itu memiliki bentuk yang sama dalam praktiknya. Dengan demikian, menyerahkan beban yang tambag pada perusahaan BUMN dalam mengoperasikan praktiknya. Dalam perusahaan yang tergolong dalam bentuk kepemilikan BUMN, program yang berkelanjutan tersebut dimanifestasikan dalam PKBL (Program Kemitraan dan Bina Lingkungan) merujuk SK PER02/MBU/7/2017. Bentuk dari program kemitraan bina lingkungan ialah suatu hal yang wajib untuk perusahaan dengan aktor kepemilikan BUMN dilaksanakanya bentuk pertanggung jawaban sosial yang diperuntukan kepada rakyat di sekitar dalam hal ekonomi, keagamaan, dan juga social (community development) ataupun program kemitraan pada sektor ekonomi. Jika ditinjau berdasarkan pada pendanaanya, CSR berdasarkan sumber anggaran dan dikalkulasikan sebagai suatu beban perseroan yang dalam pengoprasionalanya dilaksanakan dengan cara mengindahkan kewajaran dan juga kepatuhan merujuk pada pasal 74 UUPT 2007 yang mana sekarang masih berlum terdapat ketentuan mengenasi besaran persentase yang dipertimbangkan sebagai wajar, dengan demikian setiap peruahaan bisa melaksanakan penganggaran nominal CSR dengan angka yang tidak sama. Sementara itu, sumber penganggaran untuk PKBL berasal dari Sebagian keuntungan bersih yang diperoleh oleh BUMN yang dilaksanakan penyisishan berdasarakan kebutuhan dalam hal pembinaan koperasi atau usaha kecil dan juga pembinaan kepada rakyat sekitar berdasarkan pada pasal 88 UUBUMN. Implementasi dari CSR BUMN dilaksanakan dengan mempergunakan beberapa aktivitas yang sifatnya ialag berbentuk sumbangan dan juga bantuan. Bentuk dari aktivitas CSR ini lebih umum, sebab tidak terdapat pedoman yang mengatur secara ketat, sementara itu implementasi dari PKBL BUMN dioperasikan merujuk pada peraturan yang cermat.

Hasil ini mengindikasikan bahwa aktor kepemilikan BUMN yang melakukan penerbitan sustainability report sebenarnya memiliki pengaruh terhadap kinerja pasar perusahaan. Penerbitan SR yang dilakukan oleh perusahaan BUMN mampu memberikan sinyal positif terhadap aktivitas di pasar modal perusahaan sehingga memiliki kinerja pasar yang baik. Perusahaan BUMN secara lebih umum berkenaan dengan pelaksanaan pengungkapan pertanggungjawaban sosial dari perusahaan sebab perusahaan yang berjenis BUMN, saham mayoritasnya dikuasai oleh rakyat, Negara, dan juga pemerintah. Dalam menjalan aktivitas pengoperasianalanya, perusahaan BUMN dicermati secara langsung oleh Dewan Perwakilan Rakyat sebagai perwakilan dari Rakyat (Yuliarto, 2001). Hal ini tentunya tidak terlepas dari regulasi pemerintah yang begitu ketat untuk berfokus kepada kepentingan hidup hajat orang banyak. 
Tabel 2. Pengaruh sektoral dan market capital sebagai variabel kontrol pada model BUMN

\begin{tabular}{lcc}
\hline \multicolumn{1}{c}{ Keterangan } & Tanpa Variabel kontrol & Dengan Variabel kontrol \\
\hline Terhadap kinerja pasar & & $36,5 \%$ \\
Adjusted $\mathrm{R}^{2}$ & $38,4 \%$ & Negatif dan signifikan \\
Sustainability report & Negatif dan signifikan & Positif dan signifikan \\
Kinerja fundamental & Positif dan signifikan & $36,7 \%$ \\
Terhadap kinerja fundamental & & \\
Adjusted $\mathrm{R}^{2}$ & $0,8 \%$ & Positif dan tidak signifikan \\
Sustainability report & Positif dan tidak signifikan & \\
\hline
\end{tabular}

Hasil ini telah diuji menggunakan model dengan variabel kontrol dan variabel tanpa kontrol. Hasilnya menunjukkan ada atau tidaknya control dalam model ini baik menggunakan variable sektoral maupun market capital pengungkapan sustainability report BUMN memiliki sumbangan pengaruh langsung terhadap kinerja pasar perusahaan. Dengan demikian, teori signaling dapat dibuktikan pada perusahaan dengan kepemilikan BUMN. Menerbitkan sustainability report merupakan nilai lebih bagi mereka, karna mereka menyadari nilai fundamental yg lebih kecil dibandingkan BUMS membuat investor ragu untuk berinvestasi terhadap perusahaan yang menyebabkan nilai kinerja pasar BUMN lebih kecil disbanding BUMS. Maka dari itu pihak manajemen mensiasati dengan melakukan pengungkapan SR untuk meningkankan value perusahaan sehingga investor tertarik untuk berinvestasi

\section{Implikasi Manajerial}

Perusahaan bukan mencari keuntungan dari sisi finansial saja, sebab perusahaan juga melihat kalau pengungkapan dan penerapan Sustainability Report juga perlu dijadikan strategi untuk keberlanjutan bisnis perusahaan. Sebagai suatu contoh, strategi perusahaan atas remunerasi juga harus berorientasi jangka Panjang dan mempertimbangkan kepentingan stakeholder, seperti pegawai, supplier, customer, lingkungan dan masyarakat. Hal ini akan memungkinkan organisasi untuk membudayakan tanggung jawab sebagai proses bisnis inti perusahaan. Mengimplementasikan konsep berkelanjutan pada suatu bisnis bukan menjadi perihal yang mudah.

Dibutuhkan perubahan paradigma bersama dalam memahami arti keberlanjutan. Diantaranya, mengubah perspektif ekonomi jangka pendek menjadi jangka panjang yang direalisasikan dengan mengubah cara pandang konvensional yang bertujuan mengejar keuntungan jangka pendek. Sudut pandang konvensional juga belum mampu menangkap sinyal sosial dan lingkungan dalam penentuan harga pasar dan kebijakan ekonomi. Biaya konflik sumberdaya alam dan degradasi lingkungan hidup belum diperhitungkan dalam harga pasar dan kebijakan ekonomi. Karena biaya-biaya sosial dan lingkungan hidup tersebut dianggap sebagai faktor eksternal yang tidak dihitung dalam penentuan harga. Sehingga perihal tersebut yang menyebabkan kegagalan mekanisme pasar yang banyak menimbulkan distorsi dalam ekonomi dan kerusakan lingkungan secara berkelanjutan. Kegalalan mekanisme pasar harus dikoreksi melalui intervensi kebijakan publik yang tepat dan terarah. Perihal ini membutuhkan komitmen dan peran pemerintah secara penuh untuk melayani kepentingan masyarakat dan melindungi kelestarian lingkungan.

\section{KESIMPULAN DAN SARAN}

\section{Kesimpulan}

Penerapan konsep perusahaan berwawasan lingkungan pada perusahaan go public belum semuanya diterapkan. Saat ini, hanya $9 \%$ perusahaan go public yang sudah menerapkan konsep perusahaan berwawasan lingkungan. Hal ini dibuktikan dengan diterbitkannya pengungkapansustainabilityreport.Dari $9 \%$ perusahaan yang menerapkan konsep berwawasan lingkungan, $52 \%$ di antaranya merupakan perusahaan BUMN, sedangkan sisanya merupakan perusahaan BUMS. Jika dijabarkan berdasarkan sektor, persentase terendah terdapat pada sektor industri barang konsumsi, yaitu sebesar 3,57\% atau dua perusahaan yang melakukan pengungkapan sustainability report. Sektor aneka industri sebesar 5,36\% atau 3 perusahaan. Kemudian $7,14 \%$ pada sektor perdangan, jasa, investasi, serta industri dasar dan kimia, masing-masing 4 perusahaan. Untuk sektor pertanian sebesar $8,93 \%$ atau sebanyak 
5 perusahaan. Pada sektor property, real estate, dan konstruksi bangunan sebesar $10,71 \%$ atau sebanyak 7 perusahaan. Pada sektor mining dan infrastruktur sebanyak 9 laporan (16,4\% dari jumlah perusahan sektor mining dan infrastruktur). Persentase tertinggi terdapat pada sektor keuangan, yaitu sebesar 25\% atau sebanyak 14 emiten yang menerbitkan sustainability report.

Dari penelitian ini diketahui bahwa hanya rasio profitabilitas dan aktivitas saja yang berpengaruh signifikan terhadap kinerja pasar. Sementara itu, dari sisi likuiditas dan solvabilitas, tidak memengaruhi kinerja pasar. Dengan demikian, dapat dilihat bahwa pasar akan merespons positif jika perusahaan mampu mengelola dan menentukan kebijakan yang tepat untuk meningkatkan nilai rasio profitabilitas dan aktivitas perusahaan. Aktor kepemilikan yang berpengaruh negatif signifikan terhadap kinerja fundamental perusahaa. Hal ini menunjukkan jika perusahaan tersebut berbentuk BUMN, nilai kinerja fundamental lebih kecil dibandingkan dengan aktor kepemilikan BUMS. Pada hasil penelitian perusahaan BUMS (baik dikontrol dengan sektoral maupun tidak) masih banyak yang tidak menerbitkan sustainability report karena tanpa menerbitkan sustainability report pun, nilai kinerja pasar dan kinerja fundamental perusahaan BUMS sudah baik. Oleh karena itu, tidak sulit bagi manajemen untuk menarik investor agar mau berinvestasi di perusahaannya. Sementara itu, pada BUMN, penerbitan sustainability report mampu memberikan nilai tambah karena mereka menyadari nilai fundamental yang lebih kecil dibandingkan BUMS, membuat investor ragu untuk berinvestasi. Maka dari itu, pihak manajemen menyiasati dengan melakukan pengungkapan sustainability report untuk meningkankan value perusahaan.

\section{Saran}

Pemerintah dan swasta harus mampu menjalin kerja sama yang baik sehingga perusahaan di Indonesia tidak hanya berorientasi pada profit saja. Namun, mampu mengambil peran untuk mewujudkan Sustainability Report Goal Development Program (SRGDP) pada 2030 kelak. Hal ini ditujukan untuk memperoleh sustainability report financing yang terdapat dalam konsep 3P (Profit, People, and Planet) sehingga perusahaan mampu menghasilkan profit dan tetap memperhatikan dampak sosial dan lingkungan akibat dari proses bisnisnya. Investor diharapkan mampu mempertimbangkan kondisi rasio profitabilitas dan aktivitas sebelum memilih perusahaan yang akan diinvestasikan. Hal ini disebabkan, kinerja pasar diukur dengan price to book value sehingga secara teoretis dapat mengukur kinerja perusahaan dalam jangka panjang. Penelitian berikutnya sebaiknya mampu memasukkan indikator eksternal, seperti kondisi makro ekonomi di Indonesia, sehingga dapat dilihat juga faktor yang memengaruhi kinerja pasar pada indeks SRI-Kehati dan indeks LQ45. Penelitian ini dilakukan sebelum kondisi IHSG mengalami penurunan seperti saat ini, sebab pada Jumat, 6 Maret 2020, kapitalisasi pasar terus mengalami penurunan hingga mencapai 5,498.540. Supaya hasil pada penelitian selanjutnya lebih komprehensif, diharapkan pada penelitian berikutnya membagi perusahaan berdasarkan beberapa kluster: (a) Keuntungan dan besarnya anggaran sosial dan lingkungan yang meliputi: perusahaan reformis; perusahaan humanis; perusahaan ekonomis; dan perusahaan minimalis. (b) Tujuan dari pengungkapan sosial dan lingkungan yang meliputi: perusahaan pasif; perusahaan impresif; perusahaan agresif; perusahaan progresif.

\section{DAFTAR PUSTAKA}

Abiodun Y. 2012. The impact of corporate social responsibility on firm's profitability in Nigeria. European Journal of Economics, Finance and Administrative Sciences 45(45): 39-50.

Aerts W, Cornier D, Gordon IM, Magnan M. 2006. Performance disclosure on the web: An exploration of the impact of managers perceptions of stakeholder concerns. The International Journal of Digital Accounting Research 6 (12): 159-194.

Al-Najjar D. 2015. The effect of institutonal ownership on firm performance: evidence from Jordanian Listed Firms. Journal of Economics 7 (12): 97105. Tersedia pada: https://doi.org/10.5539/ijef. v7n12p97

Atkins B. 2006. Is Corporate Social Responsibility Responsible? https:// www.forbes. com/2006/11/16/leadership-philanthropycharity-lead-citizen-cx_ba_1128directorship. html\#e9908ba4a07b [10 Mar 2020]

[BEI] Bursa Efek Indonesia. 2018. Laporan Keuangan dan Tahunan Perusahaan dalam Kelompok Indeks SRI-Kehati dan LQ45. http://www.idx. co.id. [2019 Jun 02]. 
Belkaoui A, Karpik PG. 1989. Determinants of the corporate decision to disclose social information. Acounting, Auditing, and Accountability Journal 2 (1): 36-51.

Charles JK. 2017. Pengungkapan tanggung jawab social perusahaan: perspektif penjualan dan pembelian. Jurnal Manajemen dan Kebijakan 14(1): 29-36.

Chih HL, Shen CH, Kang FC. 2008. Corporate social responsibility, investor protection, and earnings management: some international evidence. Journal of Business Ethics 79(1):179-198.

Cornier D, Ledoux MJ, Magnan M. 2011. Kontribusi informasi social dan pengungkapan lingkungan untuk investor. Keputusan manajemen 49(8).

Darwin A. 2006. Sustainability Reporting/Laporan Keberlanjutan. Makalah dipresentasikan pada Temu Nasional Mahasiswa Akuntansi dalam Rangka Kongres IAI X. 2(1): 113-124.

Elkington J. 1997. Cannibal with Forks, the Tripple Bottom Line of Twentieth. London. Century Business Capstone Publishing Ltd.

FeierH,HaskellV.2008. CorporateSocialResponsibility Turns Green. Environmental Outlook.https:// www.djc.com/news/en/11202002.html. [2020 Mei 1].

Hussain N, Rigoni U, Orij RP. 2018. Corporate governance and sustainability performance: analysis of triple bottom line performance. Journal of Business Ethic 149(2). 411-432.

Jogiyanto. 2010. Metodologi Penelitian Bisnis. Yogyakarta: BPFE.
Kremer. 2007. Financial and stock market variabels as predictors of management buyouts. Strategic Management Journal 8(4): 319-327.

Praharawati G, Adyana IM, Mangunjaya FM. 2019. Pengaruh investasi csr dalam meningkatkan profitabilitas dan harga saham perusahaan yang terdaftar di indeks sri kehati periode 2011-2015. Jurnal Aplikasi Manajemen dan Bisnis 5(2): 210-221.

Salomon JF, Salomon A. 2006. Social, ethical, and disclosure personal environment. Jurnal Akuntansi, Auditi dan Akuntabilitas 19(4): 564591.

Santis P, Albuquerque A, Lizarelli. 2016. Do sustainability report companies have a better financial performance? a study on brazilian public companies. Journal of Cleaner Production 133(1): 735-745.

Spence M. 1973. Job market signaling. The Quarterly Journal of Economics 87(3): 355-374.

Wahana Lingkungan Hidup Indonesia. 2013. Perusahaan dan Pemerintah Aktor Utama Perusak Lingkungan. https://www.mongabay. co.id/2013/01/17/walhi-perusahaan-danpemerintah-aktor-utama-perusak-lingkungan2012/ [2019 Mar 7].

Yuliarto PA. 2001. Analisis faktor-faktor yang memengaruhi luas pengungkapan sukarela dalam laporan tahunan perusahaan BUMN. Jurnal Bisnis dan Ekonomi 1(15): 1-21. 